\title{
《EDEDUMASPUL
}

Vol. 5 - No. 2, year (2021), page 38-41

| $\underline{\text { ISSN 2548-8201 (Print) | 2580-0469) }}$ (Online)

\section{Peran Penting Orang Tua Terhadap Pendidikan Anak dalam Masa Pandemi di Binabo Julu, Kecamatan Barumun Baru, Kabupaten Padang Lawas}

\author{
Arlina $^{1 *}$, Wirda Juniati Hasibuan ${ }^{2}$, Fadilah Agnes Lubis ${ }^{3}$ \\ ${ }^{1}$ Universitas Islam Negeri Sumatera Utara Medan, Indonesia \\ ${ }^{2}$ Universitas Islam Negeri Sumatera Utara Medan, Indonesia \\ ${ }^{3}$ Universitas Islam Negeri Sumatera Utara Medan, Indonesia \\ * Corresponding Author. E-mail: ${ }^{1}$ arlina@uinsu.ac.id
}

\begin{abstract}
Abstrak
Penelitian ini bertujuan untuk mengkaji peran penting orangtua terhadap pendidikan anak masa pandemi Covid-19. Penelitian ini menggunakan metode kualitatif yang mengumpulkan data bukan berupa angka melainkan hasil pengamatan peneliti yang dideskripsikan secara rinci dan dengan jenis studi kasus. Setiap data dikumpulkan dengan cara observasi, wawancara dan juga dokumentasi dilapangan. Melalui penelitian ini, peneliti menemukan bahwa peran orang tua terhadap pendidikan dimasa Pandemi ini sudah cukup baik dan terpenuhi. Meskipun kebanyakan orang tua sibuk dengan pekerjaannya namun mereka juga tidak lupa memperhatikan pendidikan anaknya yang sebagian besar dilakukan dari rumah. Beberapa orang tua memang memiliki kendala terutama dengan belum adanya penyediaan smartphone yang tentunya berfungsi sebagai alat untuk melakukan pembelajaran secara Daring. Para orang tua berinisiatif untuk meminjam kepada tetangga atau saudara terdekat jika pembelajaran online dilakukan.
\end{abstract}

Kata Kunci: Pandemi, Pendidikan Anak, Peran Orang Tua.

The Important Role of Parents in Children's Education in a Pandemic Period in Binabo Julu, Barumun Baru District, Padang Lawas Regency

\begin{abstract}
This study aims to examine the important role of parents in children's education during the Covid-19 pandemic. This study uses a qualitative method that collects data not in the form of numbers but the results of researchers' observations which are described in detail and with the type of case study. Each data was collected by means of observation, interviews and also documentation in the field. Through this study, researchers found that the role of parents in education during this pandemic was quite good and fulfilled. Although most parents are busy with their work, they also do not forget to pay attention to their children's education, which is mostly done from home. Some parents do have problems, especially with the absence of a smartphone, which of course serves as a tool for online learning. Parents take the initiative to borrow from neighbors or closest relatives if online learning is carried out.
\end{abstract}

Keywords: Pandemic, Children's Education, The Role of Parents. 


\section{Pendahuluan}

Dalam masa Pandemi yang disebabkan oleh penyebaran virus Corona (Covid-19) telah membawa dampak dan pengaruh yang sangat besar baik dalam bidang ekonomi maupun pendidikan. Dampak yang sangat besar ini membuat banyak negara dengan cepat mengambil tindakan. Indonesia merupakan salah satu negara yang terkena dampak Covid-19. Kebijakan yang dilakukan pemerintah saat ini adalah dengan menerapkan PPKM ( Pemberlakuan

Pembatasan Kegiatan Masyarakat). Penerapan kebijakan ini memang sangat mempengaruhi seluruh aktivitas masyarakat terutama dalam bidang ekonomi dan pendidikan. Banyak juga masyarakat yang tidak setuju dengan kebijakan ini lantaran tidak bisa bekerja untuk memenuhi kebutuhan sehari-hari. Namun pemerintah menerapkan kebijakan tersebut demi menanggulangi wabah yang saat ini menimpa tanah air.

Meskipun aktivitas masih dibatasi, namun dunia pendidikan tidak mungkin terhenti. Untuk itu dalam bidang pendidikan pemerintah menerapkan kebijakan dengan belajar dari rumah atau Daring ( Dalam Jaringan). Seluruh pelajar diarahkan untuk belajar secara online dan tentunya harus dalam dampingan orang tua. Peran orang tua sangat dibutuhkan disini, mulai dari menyediakan smartphone dan juga paket internet. Tak lupa juga bimbingan dan arahan dari orang tua yang memudahkan anak dalam mencerna pelajaran. Pendidikan yang merupakan tonggak masa depan bangsa dan negara akan dilanjutkan meskipun tanpa tatap muka. Jadi meskipun tidak bisa bertemu secara langsung, proses belajar mengajar dilaksanakan secara online. Banyak kendala yang dihadapi selama pembelajaran secara Daring, misalnya kendala dalam jaringan internet yang kadang bermasalah, kendala pada pembiayaan data internet, dan juga perhatian lebih dari orang tua yang pastinya banyak menyita waktu untuk selalu mendampingi anaknya selama proses belajar online berlangsung.
Meskipun orang tua diajak untuk lebih berperan dalam pendidikan anaknya dimasa pandemi sekarang ini, hal ini tentunya juga demi kebaikan anak dan demi masa depan anak tersebut. Karena bagaimanapun keadaannya pendidikan tidak mungkin terhenti. Untuk itu peran orang tua sangat dibutuhkan, dilihat dari rasa suntuk dan mudahnya rasa bosan dari anak muncul karna hanya belajar dari rumah. Orang tua dituntut untuk selalu bisa mencari cara agar anak tidak mudah bosan dan tetap mau belajar seperti biasanya. Perhatian penuh orang tua dituntut untuk selalu ada terhadap anaknya. Hal ini bertujuan agar proses belajar Daring tetap berjalan tanpa banyak hambatan. Orang tua yang dapat berperan sebagai fasilitator, monivator dan direktor sangat membantu dan berperan penting ditengah pandemi sekarang ini.

Orang tua berperan sebagai pengasuh juga pendidik, pembimbing serta motivator dan fasilitator (Umar, 2015). Mengingat pentingnya peran orang tua dalam mendidik anak-anaknya, sudah banyak penelitian yang membuktikan bahwa orang tua berpengaruh besar terhadap perkembangan pendidikan anak. Pendidikan yang hanya mengandalkan pembelajaran dari sekolah saja tidaklah cukup dan menjamin anak akan berhasil. Sebaliknya orang tua sebagai faktor pendorong utama mampu memberikan semangat dan mendorong anak untuk lebih giat dalam belajar karena anak tersebut akan sadar bahwa ia belajar bukan hanya untuk kepentingannya sendiri, melainkan disana ada harapan besar dari orang tuanya.

\section{Metode}

Penelitian yang digunakan adalah metode kualitatif, dimana yang diukur bukan berupa angka melainkan penjelasan dari peneliti saat mengamati objek. Penelitian ini menggunakan jenis studi kasus. Studi kasus sendiri adalah salah satu jenis penelitian dimana peneliti bereksplorasi secara langsung dan mendalam terhadap aktifitas, proses dan 
kejadian terhadap sampel penelitiannya (Sugiyono, 2016). Wawancara, observasi dan dokumentasi merupakan teknik pengumpulan data dari penelitian ini. Teknis analisis data yang digunakan adalah teknik dari Miles dan Hubermant yaitu dengan menggunakan tringulasu teknik dan tringulasi sumber. Sumber data atau subjek penelitian ini adalah masyarakat terutama orang tua dan guru di desa Binabo Julu.

\section{Hasil dan Pembahasan}

\section{Pembelajaran Daring di Masa Pandemi}

Proses belajar mengajar yang awalnya berlangsung secara langsung atau tatap muka sudah terhenti pelaksanaannya dikarenakan wabah virus covid-19 yang menyebar diberbagai negara didunia khususnya Indonesia. Pembelajaran yang harusnya berjalan lancar dan menyenangkan bagi peserta didik kini ibarat membeku karna hanya berlangsung dari rumah. Pemerintah menerapkan kebijakan ini demi tidak ingin meluasnya wabah penyebaran virus Corona dan dengan kebijakan ini diharapkan wabah tidak lagi meluas dan bisa segera terbasmi agar keadaan kembali seperti semula. Meskipun ada beberapa faktor yang menghambat berjalannya pembelajaran secara Daring seperti masalah jaringan, biaya internet dan pembelian smartphone, Pemerintah dengan sigap memberikan bantuan kepada para pelajar yang sedang melaksanakan pembelajaran dari rumah. Pemberian bantuan berupa data internet gratis dan berbagai macam bantuan yang diberikan kepada masyarakat diharapkan dapat membawa keringan bagi orang tua yang berperan sangat penting bagi kelangsungan hidup anaknya.

Pembelajaran Daring di desa Binabo Julu belum berjalan sesuai yang diharapkan. Hal ini dikarenakan banyaknya kendala baik itu berupa biaya untuk membeli Smartphone dan data internet juga kendala akan waktu dari orang tua. Masyarakat di Binabo Julu yang sebagian besar bermata pencaharian sebagai petani tentunya tidak dapat membagi waktu untuk memberikan perhatian penuh terhadap pendidikannya anaknya. Padahal dimasa pembelajaran Daring seperti sekarang ini peran orang tua sangatlah penting sekali untuk keberlangsungan pendidikan anaknya. Untuk itu demi memaklumi keadaan masyarakat, pemerintah setempat mengarahkan sekolah untuk tetap melakukan proses belajar mengajar secara langsung atau tatap muka tapi dengan syarat harus membuat shift. Hanya ada satu atau dua kelas saja yang boleh hadir dalam satu hari untuk melakukan pembelajaran tatap muka. Hal ini demi tetap terlaksana dan terjaganya protokol kesehatan yang diharapkan tidak melebarnya wabah virus Corona. Tak lupa juga pemerintah setempat melakukan kebijakan ini dikarenakan situasi didaerah tersebut yang masih dapat disebut cukup aman dari virus Corona. Namun demi menjaga agar wabah virus tidak semakin menyebar dari para pendatang yang datang ke daerah tersebut.

Anak-anak di Desa Binabo Julu melakukan pembelajaran tatap muka dua sampai tiga kali dalam seminggu, selebihnya pembelajaran dilakukan secara Daring. Pelaksanaan pembelajaran secara langsung tersebut tidak lupa menerapkan protokol kesehatan dengan mewajibkan peserta didik memakai masker dan menjaga jarak serta menggunakan antiseptik setiap mencuci tangan. Anak-anak yang belum memiliki smartphone bisa meminjam kepada tetangga atau saudara terdekat selama pembelajaran dimulai. Hal ini dilakukan masyarakat agar anaknya tidak ketinggalan pelajaran dan agar proses belajar anaknya berjalan dengan baik. Para orang tua juga sebisa mungkin membagi waktu agar bisa membimbing dan membantu anaknya selama pembelajaran Daring.

\section{Peran Orang Tua Terhadap Pendidikan Anak di Masa Pandemi}

Pendidikan adalah sesuatu yang meletak dalam jiwa manusia bahkan semenjak ia dapat berintraksi atau 
berkomunikasi dengan keluarga terdekatnya yaitu keluarga.Orang tua sebagai orang pertama yang dikenal anak dan orang pertama berintraksi dengan anak adalah motivator utama.Pendidikan pertama anak tumbuh dari lingkungan keluarga, sehingga pertama kali smendapatkan bimbingan serta pendidikan bukan dari lingkungan sekolah melainkan dari lingkungan keluarg. Keluarga memiliki tugas utama dalam pendidikan anak, sebagai acuan dasar mengenai pendidikan keagamaan, budaya,serta nilai norma dan modal dalam bersosialisasi dalam lingkungan dan masyarakat yang luas, terutama dalam lingkungan kekeluargaan dan disekitar tempat tinggal.

Kepedulian orang tua merupakan faktor utama dalam penentuan keberhasilan anak dalam belajar, dalam menjaga dan membina perkembangan anak dari segi fase ke fase, yaitu pada awal perkembangan dan pertumbuhan anak, tidak lain dalam faktor eksternal. Pendidikan anak terutama pada anak usia dini ,tatanan dasar dalam membangun kepribadian anak. Kesatuan antara ibu dan ayah menjadi faktor yang terpenting dalam mengasah dan membentuk karakter dan kepribadian seorang anak. Anak yang sudah di latih oleh orang tuanya dalam hal nya membentuk kepribadian yang membangun karakteristik yang baik, maka anak tersebut akan lebih mudah meningkatkan kemampuan yang sudah di milikinya sejak usia dini. Pendidikan dalam keluarga menjadi salah satu upaya untuk mencerdaskan kehidupan bangsa melalui pengalam yang sudah didapatkan seumur hidup.

Kita semua tentunya sudah tahu bahwa saat ini dunia sedang dilanda masalah yang tidak biasa yaitu dengan kemunculan virus Corona atau lebih dikenal dengan covid-19. Virus ini tidak hanya mengancam kesehatan masyarakat melainkan juga perekonomian dan pendidikan. Mendikbud menertibkan Surat Edaran Nomor 4 Tahun 2020 tentang Pelaksanaan Pendidikan dalam Masa Darurat Covid-19 bahwa penerapan belajar dari rumah berarti guru harus senantiasa berkomunikasi dengan orang tua dalam rangka membantu siswa mengerjakan tugasnya.

Peran orang tua dalam pendidikan anak di era pandemi di Desa Binabo Julu Kecamatan Barumun Baru, Kabupaten Padang Lawas, orang tua diberikan tugas dalam mengawasi anak-anak nya terutama anak di usia dini, karena umunya orang tua merupakan pendidik utama bagi anak. Hal tersebut sudah dijalakan oleh orang tua selama terdapat atauran untuk belajar dari rumah. Mencipkakan lingkungan belajar telah direalisasikan oleh orang tua sesuai dengan strategi masig-masing keluarga di Desa Binabo Julu.

Sebagian tugas yang diberikan oleh guru dilakukan melalui sebuah aplikasi berupa WhatsApp yang memberikan rendahnya interaksi atara guru dan siswa. Guru perlu menyusun rancangan pembelajaran dengan lebih memperhatikan kemaksimalan tingkat interaksi antara guru dan siswa. Dan orang tua berpedoman terhadap pengetahuan dan pemgalaman dalam pendidikan anak sehingga orang tua dijadikan contoh oleh anak-anak,terutama anak di usia dini. Orang tua menciptakan kenyaman belajar anak yang dijadikan sebagai landasan semangat belajar pada anak sehingga anak tidak banyak alasan dalam belajar. Karena anak memiliki rasa ingin tahu yamg besar sehingga dalam pelaksanaan pendidikan dari rumah perlu memperhatikan kenyamanan belajar anak sehingga tidak berakibat anak kurang bersemangat ketika sedang belajar. Pola asuh orang tua sangat berpengaruh dalam mengembangkan atau menghambat perkembangan kecerdasan anak.

Selama penelitian berlangsung peneliti sedang melaksanakan KKN-DR. Melihat kondisi pembelajaran Daring yang membuat anak-anak cepat merasa bosan dan suntuk, maka Mahasiswa KKN-DR UINSU berinisiatif mengadakan sebuah festival anak dengan tema keagamaan. Anak-anak di desa tersebut sangat gembira menyambut festival lomba yang diadakan. 
Adapun acara dalam lomba tersebut adalah lomba adzan, lomba membaca surah pendek, lomba menyanyi lagu religi dan yang terakhir adalah lomba mewarnai. Festival lomba anak Soleh tersebut diadakan dan dipanitiai oleh Mahasiswa KKN-DR UINSU. Masyarakat pun tidak ketinggalan dalam berpartisipasi untuk acara tersebut dengan menyumbangkan dana seadanya. Mahasiswa dibantu oleh para pemuda di desa Binabo Julu tersebut berhasil memeriahkan dan mensukseskan festival lomba. Penerapan protokol kesehatan tidak lupa diterapkan dalam acara ini demi membatasi penyebaran wabah virus. Anak-anak merasa senang dan terhibur dengan adanya acara ini. Dalam seketika rasa suntuk dan bosan mereka dapat di atasi dan membuat mereka menemukan hal baru dan semangat baru untuk melanjutkan pendidikan dimasa Pandemi ini.

\section{Simpulan}

Pandemi Covid-19 membuat peran orang tua sebagai pendidik utama bagi anaknya harus berperan penuh dan meluangkan waktu terhadap proses belajar Daring yang berlangsung dari rumah. Setiap keluarga memiliki cara yang berbeda dalam melaksanakan pendidikan di rumah semasa pandemi covid-19 saat ini. Banyak kalangan masyarakat yang belum sepenuhnya mendapatkan pembelajaran semestinya.
Orang tua sangat berperan penting terhadap membentuk kepribadian anak. Orang tua telah berhasil menciptakan suasana belajar yang nyaman dengan memberikan fasilitas belajar yang memadai sehingga anak tersebut tambah bersemangat dalam belajar. Orang tua harus melakukan pengawasan terhadap anaknya dalam mengerjakan tugas anak, dan memberikan reward kepada anaknya. Sistem proses belajar mengajar di Desa Binabo Julu Kecamatan Barumun Baru Kabupaten Padang Lawas di masa pandemi covid-19 saat ini, proses pembelajarannya dilaksanakan dengan tatap muka dan akan tetapi tetap mematuhi protokol kesehatan.

\section{Daftar Pustaka}

[1] Aji, T. (2020). Pendidikan Karakter di Masa Pandem, Menjadi Tanggung Jawab Siapa? Jakarta: Kemenag.go.id.

[2] Putra, I.P. (2020). Orang Tua Paling Menentukan Pendidikan Anak di Usia Dini Saat Pandemi. Jakarta: Medcom.id.

[3] Sudirman. (2013). Perhatian Orang Tua dalam Motivasi Belajar Siswa. Jurnal Madaniyah, 11(2).

[4] Sugiyono. (2016). Metode Penelitian Manajemen. Bandung: Alfabeta.

[5] Umar, M. (2015). Peran Orang Tua dalam Peningkatan Prestasi Belajar Anak. JURNAL EDUKASI: Jurnal Konseling. https://doi.org/10.22373/je.v1i1.315. 